\title{
Long Jump Learning Model Using Play Approach
}

\author{
Wondo Wibowo ${ }^{1 *}$ and Hartati ${ }^{2}$ \\ ${ }^{I}$ Faculty of Sport Science, Universitas Negeri Padang, Padang, Indonesia \\ ${ }^{2}$ Universitas Sriwijaya, Palembang, Indonesia \\ *Corresponding author. Email: wondowibowo@yahoo.com
}

\begin{abstract}
This study was aimed to produce a long jump learning model product using play approach for fifth grade students of elementary school. The Method used research and development. The procedures consists of; analysis of needs for initial product, initial product development, product validation and evaluation by experts, small-scale product tests, product revisions, large-scale tests and final product. The result showed that the validity of the product from the physical experts was 4.75 with a very valid category. Validation from learning experts obtained was 4.83 with a very valid category. Based on expert validation, the average score of 4.79 was included in the very valid category. Smallscale tests obtained score in the value of students skills was 81 with a good category. The results of the value of students attitudes was 82 with a good category and the results of the value of student knowledges was 83 in the good category. The level of student motivation in small-scale test was 83 in the high motivation category. Large-scale test on student skills obtained was $\mathrm{N}$-gain of 0.5 in the medium category, with the results of the value of student attitudes obtained was 84 with good categories and the results of student knowledges obtained was 82 in the good category. Student motivation levels was high with an average score of 85 . Based on the reaserch, long jump learning model using play approach was proved more effective and efficient, thus increasing student achievement and motivation in learning. The implication of the long jump learning model research using the play approach needs to be developed and can be applied to long jump learning.
\end{abstract}

Keywords: learning model, long jump, play approach

\section{INTRODUCTION}

Physical Education is a subject part of education carried out systematically through physical activities to develop individuals in aspects of skills, knowledge, attitudes and social. Physical education is an integral part of overall education through a variety of physical activities aimed at developing individuals organically, neuromiculately, intellectually and emotionally [1].

Physical education is very much needed in education, both in elementary, middle and high school. Physical and health education subjects (Physical Education) are indeed very emphasized on the Psychomotor aspects (skills), one of the material taught in Physical Education is athletic material.

According to Suyono, Athletics is defined as comparative / pitted physical activity, including separate numbers based on basic human movement abilities such as walking, running, jumping, and throwing [2]. Athletic learning includes road, run, jump and throw numbers. Long jump is an athletic material that is included in the jump number. Long jump can be seen from the technique of movement can be divided into several stages, namely, prefix, pedestal or repulsion, hovering and landing. Long jump is a learning material that is in the curriculum in elementary schools [3].

Primary school age the child develops socially, making his first contact with other parties through movement activities. In children as in general children love to run and be happy [2]. Based on the characteristics of these students required an appropriate learning model to achieve learning objectives. In learning to jump in elementary school the teacher uses a learning model that is monotonous and less varied so that students are less enthusiastic when taking lessons. Based on observations by conducting interviews with Physical Education teachers at SD Negeri 16 Tanjung Batu that students are less enthusiastic when taking long jump lessons, students prefer playing material such as playing soccer. The learning model used by the teacher is not in accordance with the characteristics of children who enjoy playing, running and having fun.

The learning model is a plan or pattern that is used as a choice that is used to form a learning plan, which is appropriate and efficient to achieve educational goals. The learning model is a plan or pattern that is used as a guide in class learning planning or tutorial learning [4]. According to Joy \& Weil quoted, argues 
that the learning model is a plan or pattern that can be used to shape the curriculum (long-term learning plan), design learning materials, and guide learning in class or other [5].

The play approach is a form of learning that is given in all levels of education which are conceptualized into a game or game situation. Approach to play is a form of physical education learning that is given at all levels of education, only the portion and form of the game must be adjusted to aspects that exist in the curriculum [6]. According to Wahjoedi, that the approach to play is learning that is given in the form or situation of the game [7].

Based on research conducted by Adzka (2013) the results of a limited trial of the sportedukatif Play Learning Model in Athletic Learning show that the average gain $(\mathrm{g})=0.7$ which means this learning model is effective in increasing student mastery of subject matter [8].

Similarly, research conducted by Maksum (2017) found that: (1) a new model of long jump learning with games can improve multilateral movement for students; and (2) new models of long jump learning with games more effective and efficient so as to increase achievement, interest, and motivation for students in learning physical education. The development of the basic long jump learning model with long jump games is one of the efforts to help students to follow the long jump basic motion learning to be active, creative, effective, safe, happy, and fun [9].

Based on these problems learning models are needed using the play approach. The development of long jump learning with the play stage is expected to make students more active in various pleasant situations and conditions and emphasizes aspects of students' skills, attitudes and knowledge.

\section{RESEARCH METHODS}

This research uses research and development (R\&D) methods. According to Borg \& Gall research and development is a process used to develop or validate products used in education and learning [10].

According to Bord and Gall research and development methods (research development) is a process used to develop and validate educational products and determine new knowledge through "base research" and aim to provide educational changes for to increase the potential positive impacts of research findings in solving educational problems and are used to improve the performance of educational practices, including through learning in the form of research [11].

The procedure used in this study uses 7 steps, the steps include; analysis of initial product requirements, initial product development, expert validation and evaluation, small-scale product trials, product revisions, large-scale tests and final products [12].

Data collection techniques used are the form of evaluation sheets, questionnaires, written tests and practice tests. Evaluation sheets are used to collect validation data from physical education experts and learning experts. The questionnaire is used to assess student attitudes by asking students to express their strengths and weaknesses in achieving competence. Written tests are generally used to assess student learning outcomes in the mastery of knowledge competencies. Practice tests are used to assess long jump skills, this practice test uses observation guidelines in the form of a checklist sheet about basic motion in long jump.

Attitude assessment sheet Attitude assessment includes several indicators in the assessment of long jump learning attitudes namely, sportsmanship, discipline, cooperation, enthusiasm, respect for others. The knowledge instrument uses a written test, a written test in which the test questions or questions are given to students to get answers in written form. This test uses a multiple-choice test (multiple-choice).

Skills assessment (psychomotor) related to the skills or abilities of students in moving or acting. This assessment uses a practice test or better known as a test of performance (performance.

Analysis of the product learning model test using the Gain or n-gain Normality Test. This test is used to determine the improvement of long jump skills before and after learning after the long jump learning model is applied using a play approach. Analysis of this data uses the $\mathrm{N}$-gain formula as follows [13]

$\langle g\rangle=\frac{\langle \% s f>-<\% \text { si }>}{s m-<\% \text { si }>}$

Information:

$\mathrm{g}=$ average normalized gain score

$\mathrm{Sf}=$ final score (post-test)

$\mathrm{Si}=$ initial score (pre-test)

$\mathrm{Sm}=$ maximum score

The table of the obtained gain score criteria can be seen in the table below [13]

Table 1. Gain Score Criteria

\begin{tabular}{cc}
\hline Criteria & Category \\
\hline $\mathrm{g}>0,7$ & High gain score \\
$0,3<\mathrm{g}<0,7$ & Medium gain score \\
$\mathrm{g}<0,3$ & Low gain score \\
\hline
\end{tabular}

Hake (Simbolon, 2015) 


\section{RESULTS AND DISCUSSION}

\section{A. Validation Results}

The validation of the learning model product is carried out by Physical Education experts and learning experts [14].

Table 2. Classification of Validation

\begin{tabular}{|c|c|}
\hline Average Score & Criteria \\
\hline $4,21-5,00$ & Very Valid \\
\hline $3,41-4,20$ & Valid \\
\hline $2,61-3,40$ & Valid enough \\
\hline $1,81-2,60$ & Invalid \\
\hline $1,00-1,80$ & Very Invalid \\
\hline
\end{tabular}

(Widoyoko, 2012)

The results of the assessment conducted by Physical Education experts obtained 4.75 validation results in the very valid category. The results of learning validation obtained 4.83 results with a very valid category. Based on the validation assessment conducted by experts obtained an average of 4.79 which is included in the very valid category.

\section{B. Small Scale Trial Results}

Small-scale trials were conducted with 10 subjects. Small-scale trials carried out by observing the basic long jump squat style technical skills consisting of 3 indicators, namely; prefix, repulsion, float and land.

The following are the results of the skills assessment categorized in the evaluation criteria table [15]

Table 3. Test Skill Results try Small Scale

\begin{tabular}{|c|c|c|c|}
\hline Category & Score & $\begin{array}{c}\text { Many } \\
\text { students }\end{array}$ & $\%$ \\
\hline Very good & $91-100$ & 2 & $20 \%$ \\
\hline Well & $71-90$ & 6 & $60 \%$ \\
\hline Enough & $61-70$ & 2 & $20 \%$ \\
\hline Less & $>60$ & 0 & $0 \%$ \\
\hline amount & & $\mathbf{1 0}$ & $\mathbf{1 0 0}$ \\
\hline Average & $\mathbf{8 1}$ & & \\
\hline
\end{tabular}

(Komarudin, 2016)

The results of students' skills with a very good category are 2 students or $20 \%$, good categories are as many as 6 students or $60 \%$, and enough categories are as many as 2 students or $20 \%$. The results of the average value of student skills is 81 with a good category.

Following are the results of the attitude assessment which is categorized into the criteria table. The results of the attitude assessment can be seen in the table below [15].
Table 4. Results of Attitude Assessment of Small Scale Trials

\begin{tabular}{|c|c|c|c|}
\hline Category & Score & $\begin{array}{c}\text { Many } \\
\text { students }\end{array}$ & $\boldsymbol{\%}$ \\
\hline Very good & $91-100$ & 3 & $30 \%$ \\
\hline Well & $71-90$ & 5 & $50 \%$ \\
\hline Enough & $61-70$ & 1 & $10 \%$ \\
\hline Less & $>60$ & 1 & $10 \%$ \\
\hline amount & & $\mathbf{1 0}$ & $\mathbf{1 0 0 \%}$ \\
\hline Average & $\mathbf{8 2}$ & & \\
\hline
\end{tabular}

(Komarudin, 2016)

Students who get attitude scores in the excellent category are 3 students or $30 \%$, students who get grades in the good category are 5 students or $50 \%$, students who get enough grades in the category are 1 student or $10 \%$ and students who score in the category are less 1 student or $10 \%$. Attitude assessment obtained average results in small scale trials of 82 with good categories.

Following are the results of the assessment of students' knowledge in small-scale trials categorized into the assessment criteria table [15]

Table 5. Results of the Small Scale Test Knowledge Assessment

\begin{tabular}{|c|c|c|c|}
\hline Category & Score & $\begin{array}{c}\text { Many } \\
\text { students }\end{array}$ & $\%$ \\
\hline Very good & $91-100$ & 3 & $30 \%$ \\
\hline Well & $71-90$ & 4 & $40 \%$ \\
\hline Enough & $61-70$ & 2 & $20 \%$ \\
\hline Less & $>60$ & 1 & $10 \%$ \\
\hline amount & & $\mathbf{1 0}$ & $\mathbf{1 0 0 \%}$ \\
\hline Average & $\mathbf{8 3}$ & & \\
\hline
\end{tabular}

(Komarudin, 2016)

The results of student knowledge in small-scale trials in the excellent category were 3 students or $30 \%$, the good category was 4 students or $40 \%$, the category was quite as much as 2 students or $20 \%$ and in the category there were less than 1 student or $10 \%$. The average value of student knowledge is 83 in the good category.

Here are the results of the level of student motivation when participating in long jump learning using the play approach [15]. 
Table 6. Motivation Levels of Small Scale Test Students

\begin{tabular}{|c|c|c|c|}
\hline Category & Score & $\begin{array}{c}\text { Many } \\
\text { students }\end{array}$ & $\%$ \\
\hline Very good & $91-100$ & 5 & $50 \%$ \\
\hline Well & $71-90$ & 3 & $30 \%$ \\
\hline Enough & $61-70$ & 2 & $20 \%$ \\
\hline Less & $>60$ & 0 & $0 \%$ \\
\hline amount & & $\mathbf{1 0}$ & $\mathbf{1 0 0 \%}$ \\
\hline Average & $\mathbf{8 3}$ & & \\
\hline
\end{tabular}

(Komarudin 2016)

Students who have very high motivation when participating in learning are 5 students or $50 \%$, students who have high motivation are 3 people or $30 \%$ and students who have moderate motivation are 2 students or $20 \%$. Student motivation on small scale tests with an average of 83 in the high category.

\section{Large Scale Trial Results}

Large-scale trials conducted with a total of 35 students. Large-scale test before students are given a long jump learning model using the approach to playing students are given the initial test (pretest) long jump first then at the end of learning students are given the final long jump test (posttest).

Long jump students are taken through the student performance sheet on the basic motion of the long jump, then at the end of the learning students fill out the questionnaire aspects of attitude and motivation and cognitive to determine student understanding in terms of knowledge. Pretest [15].

Here are the results of the large-scale Skill Test

Table 7. Pretest Results of Large Scale Test Skills

\begin{tabular}{|c|c|c|c|}
\hline Category & Score & $\begin{array}{c}\text { Many } \\
\text { students }\end{array}$ & $\%$ \\
\hline Very good & $91-100$ & 0 & $0 \%$ \\
\hline Well & $71-90$ & 7 & $20 \%$ \\
\hline Enough & $61-70$ & 23 & $66 \%$ \\
\hline Less & $>60$ & 5 & $14 \%$ \\
\hline amount & & $\mathbf{3 5}$ & $\mathbf{1 0 0 \%}$ \\
\hline Average & $\mathbf{6 6}$ & & \\
\hline
\end{tabular}

(Komarudin, 2016)

The results of the initial tests of students' skills were in the sufficient category, which was $66 \%$ while the rest in the good category was $20 \%$ and $14 \%$ less category. The average Pretest result of long jump skills is 66 in the sufficient category.

Following are the results of Posttest student skills on a large scale test [15].
Table 8. Results of Posttest Large Scale Test Skills

\begin{tabular}{|c|c|c|c|}
\hline Category & Score & $\begin{array}{c}\text { Many } \\
\text { students }\end{array}$ & \% \\
\hline Very good & $91-100$ & 6 & $17.14 \%$ \\
\hline Well & $71-90$ & 25 & $71.43 \%$ \\
\hline Enough & $61-70$ & 4 & $11.43 \%$ \\
\hline Less & $>60$ & 0 & $0.0 \%$ \\
\hline amount & & $\mathbf{3 5}$ & $\mathbf{1 0 0 \%}$ \\
\hline Average & $\mathbf{8 3}$ & & \\
\hline
\end{tabular}

(Komarudin, 2016)

The final test results of students' skills in the excellent category were 6 students or $17.14 \%$, in the good category were 25 students or $71.43 \%$. In the category enough as many as 4 students or $11.43 \%$. The average end result of student skills is 83 in the good category.

Following are the results of evaluating student attitudes on a large scale test [15].

Table 9. Results of the Attitudes of Large Scale Test Students

\begin{tabular}{|c|c|c|c|}
\hline Category & Score & $\begin{array}{c}\text { Many } \\
\text { students }\end{array}$ & \% \\
\hline Very good & $91-100$ & 12 & $34 \%$ \\
\hline Well & $71-90$ & 20 & $57 \%$ \\
\hline Enough & $61-70$ & 3 & $9 \%$ \\
\hline Less & $>60$ & 0 & $0 \%$ \\
\hline amount & & $\mathbf{3 5}$ & $\mathbf{1 0 0 \%}$ \\
\hline Average & $\mathbf{8 4}$ & & \\
\hline
\end{tabular}

Komarudin (2016)

The results of the students' attitudes when participating in the long jump learning approach to playing in the excellent category were 12 students or $34 \%$, in the good category were 20 students or $57 \%$ and in the category quite as many as 3 students or $9 \%$. The average student attitudes were 84 in the good category.

Here are the results of student knowledge on a large scale test [15].

Table 10. Results of knowledge on the Large Scale test

\begin{tabular}{|c|c|c|c|}
\hline Category & Score & $\begin{array}{c}\text { Many } \\
\text { students }\end{array}$ & $\boldsymbol{\%}$ \\
\hline Very good & $91-100$ & 7 & $20 \%$ \\
\hline Well & $71-90$ & 18 & $51 \%$ \\
\hline Enough & $61-70$ & 8 & $23 \%$ \\
\hline Less & $>60$ & 2 & $6 \%$ \\
\hline amount & & $\mathbf{3 5}$ & $\mathbf{1 0 0 \%}$ \\
\hline Average & $\mathbf{8 2}$ & & \\
\hline
\end{tabular}

Komarudin (2016) 
The results of student knowledge when participating in the long jump learning approach to playing in the excellent category were 7 students or $20 \%$, in the good category as many as 18 students or $51 \%$, in the category quite as many as 8 students or $23 \%$ and in the less category as many as 2 students or $6 \%$ The average student knowledge yield of 82 in both categories [15].

Table 11. Motivation Levels of Large Scale Student Tests

\begin{tabular}{|c|c|c|c|}
\hline Category & Score & $\begin{array}{c}\text { Many } \\
\text { students }\end{array}$ & $\mathbf{\%}$ \\
\hline Very good & $91-100$ & 19 & $54 \%$ \\
\hline Well & $71-90$ & 10 & $29 \%$ \\
\hline Enough & $61-70$ & 6 & $17 \%$ \\
\hline Less & $>60$ & 0 & $0 \%$ \\
\hline amount & & $\mathbf{3 5}$ & $\mathbf{1 0 0 \%}$ \\
\hline Average & $\mathbf{8 3}$ & & \\
\hline
\end{tabular}

(Komarudin 2016)

Students who have very high motivation when participating in learning are 19 students or $54 \%$, who have high motivation are 10 students or $29 \%$ and who have moderate motivation are 6 students or $17 \%$. Student motivation when large-scale test averaged 85 in the high category.

\section{DISCUSSION}

Needs analysis is done by conducting observations and interviews directly to the physical education teacher at SD Negeri 16 Tanjung Batu, from direct interviews that students have less interest when taking long jump lessons. Students during Physical Education only want to learn Physical education related to games, such as playing football, students do not like athletic lessons such as long jump. Based on these problems, it is necessary to develop a long jump learning model using a play approach.

The product of the learning model before it is tested in the field is validated and evaluated by the Physical Education and Learning Expert. Physical education validation results and learning average validation and expert evaluation results are 4.79 which are included in the category of very valid and feasible products continue to be used in small-scale trials.

The results of small-scale trials with a total of 10 students obtained the average value of student skills is 81 with a good category. Attitude assessment obtained average results in small-scale trials of 82 with good categories and the average value of student knowledge is 83 in the good category. The motivation level of students was 83 with a high motivation category. Based on the results of the evaluation on a small scale trial, then the next test is conducted on a larger scale.

The results of large-scale tests carried out by a total of 35 students. Large-scale student tests are given a preliminary test on student skills. In the preliminary test students get a jump skill score with an average of 66 in the sufficient category.

Students are then given a long jump learning model of learning with a play approach. At the end of learning students are given the final long jump skill test. Final test results obtained an average of 83 in the good category. After completing the final long jump test the students filled out the questions and questionnaire assessing attitude and motivation. The results of attitudes assessment results obtained by 84 in the category of good, and the results of knowledge by 82 in the good category. The level of student motivation on a large scale test, amounting to 85 in the high motivation category.

To find out the improvement of long jump skills before and after learning after the long jump learning model is applied using a play approach using the Gain or n-gain Normality Test. Calculating the ability of pretest and post-test skills is to calculate $\mathrm{N}$-gain. The result of $\mathrm{N}$-gain is 0.5 , then $0.3<0.5<0.7$, thus this learning product has a potential effect in the medium category. These results are in accordance with the opinion of Maksum (2017) Long jump learning model with a more effective and efficient game that increases achievement, interest, and motivation for students in learning physical education [9].

\section{CONCLUSIONS AND SUGGESTIONS D. Conclusion}

Based on the results of small-scale trials and large-scale trials of learning models using the play approach provides a potential effect on learning outcomes in long jump learning with $\mathrm{N}-$ Gain 0.5 in the medium category. The long jump learning model using the play approach can be applied to learning for elementary school students.

\section{E. Suggestion}

When presenting physical education material, it is packaged as attractive as possible. In Physical Education learning the material to be delivered should be designed using a learning model in accordance with student characteristics.

The long jump learning model using the play approach can be used as an alternative by the teacher to be used in long jump learning in elementary schools. 


\section{REFERENCES}

[1] S. Safariatun, Azas dan Falsafah Pendidikan Jasmani, Jakarta: Universitas Terbuka, 2008.

[2] V. G. Simanjutak, Bahan ajar cetak. Pendidikan Jasmani dan Kesehatan, Jakarta: Departemen Pendidikan Nasional, Direktorat Jenderal Pendidikan Tinggi, 2009.

[3] E. Purnomo, Pedoman Mengajar Dasar Gerak Atletik Fakultas Ilmu Keolahraga, Yogyakarta: Universitas Negeri Yogyakarta, 2007.

[4] Hartati, "Pembelajaran Bulu Tangkis Secara Langsung Dan Tidak Langsung Terhadap Prestasi Belajar Mahasiswa S1 Penjaskes Semester V Fkip Unsri 2 (2), Halm," Jurnal Ilmu Olahraga dan Kesehatan, vol. 2, no. 2, pp. 9-20, 2013.

[5] Rusman, Model-Model Pembelajaran. Mengambangkan Profesionalisme Guru, Jakarta: PT. RajaGrafindo Persada, 2013.

[6] Halidin, "Upaya menigkatakan minat mengikuti pembelajaran penjaskes dengan metode bermain," Jurnal pendidikan jasmani kesehatan dan rekreasi, vol. 1, no. 1, pp. 28-32, 2012.

[7] K. Prasetyo, "Penerapan Pendekatan Bermain Untuk Meningkatkan Hasil Belajar Lompat Jauh Gaya Jongkok Pada Siswa Kelas 5 Sekolah Dasar," Jurnal Pendidikan dan Kebudayaan, vol. 6, no. 3, pp. 196-205, 2016.

[8] A. Adzka, Herpratiwi dan R. Hermawan, "Pengembangan Model Pembelajaran Bermain Sportedukatif Dalam Pembelajaran Atletik Di Smp Negeri 2 Pringsewu.," Jurnal Teknologi Informaasi Komunikasi, vol. 1, no. 8, pp. 1-15, 2013.

[9] H. Maksum, "Pengembangan Model Pembelajaran Gerak Dasar Lompat Jauh dengan Permainan," Jurnal Pendidikan Olahraga, vol. 6, no. 1, pp. 4253, 2017.

[10] Hartati, Destriana dan S. Aryanti, "Multimedia Development On Sports Health Subject For Third Semester Students Of Penjaskes Fkip Unsri," Proceedings of the 2nd SULE - IC 2016, vol. 2, no. 1, pp. 469-484, 2016.
[11]Aunurrahman, Bahan ajar cetak. Pendidikan tindakan SD, Jakarta: Departemen Penddikan Nasional, Direktorat Jenderal Pendidikan Tinggi., 2009 .

[12] Sugiyono, Metode Penelitian Pendidikan (Pendekatan Kuatitatif, Kualitatif, dan R\&D), Bandung: Alfabeta, 2016.

[13]E. R. Simbolon dan F. S. Topolouw, "Pengaruh Pembelajaran Berbasis Dan Pembelajaran Konstekstual Terhadap Berfikir Kritis Siswa SMP," Jurnal Center For Sciense Education, vol. VIII, no. I, pp. 97-104, 2015.

[14]E. P. Widoyoko, Teknik Penyusunan Instrumen Penelitian, Yogyakarta: Pustaka Belajar, 2012.

[15] Komarudin, Penilaian Hasil Belajar. Pendidikan Jasmani dan Olahraga, Bandung: PT. Remaja Rosdakarya, 2016. 